Int. J. Dev. Biol. 63: 123-130 (2019)

https://doi.org/10.1387/ijdb.180324mc

\title{
Somatic cell nuclear transfer: failures, successes and the challenges ahead
}

\author{
MARTA CZERNIK ${ }^{1,2}$, DEBORA A. ANZALONE¹, LUCA PALAZZESE¹, MAMI OIKAWA ${ }^{\#, 3}$ and PASOUALINO LOI*, \\ ${ }^{1}$ Faculty of Veterinary Medicine, University of Teramo, Teramo, Italy, ${ }^{2}$ Department of Experimental Embryology, Institute of \\ Genetics and Animal Breeding of the Polish Academy of Sciences, Jastrzębiec, Poland and ${ }^{3}$ Center for Genetic Analysis of \\ Behavior, National Institute for Physiological Sciences, National Institutes of Natural Sciences, Okazaki, Japan
}

\begin{abstract}
Somatic cell nuclear transfer (SCNT) has a broad spectrum of potential applications, including rescue of endangered species, production of transgenic animals, drug production, and regenerative medicine. Unfortunately, the efficiency of SCNT is still disappointingly low. Many factors affecting cloning procedures have been described in several previous reviews; here we review the most effective improvements in SCNT, with a special emphasis on the effect of mitochondrial defects on SCNT embryo/ foetus development, an issue never touched upon before.
\end{abstract}

KEY WORDS: somatic cell nuclear transfer, SCNT, nuclear reprogramming, mitochondria

\section{Introduction}

The latest Red List of the International Union for Conservation of Nature (IUCN) shows that $21 \%$ of all mammals as threatened. The worst news is that the global number is likely underestimated due to lack of recent data from more than $58 \%$ of breeds, therefore classified as unknown risk (FAO, 2018).

To keep up with this alarming situation, it has been suggested that genetic banks, mainly in the form of cell lines (preferably fibroblast), should be established for critically threatened species. Scientists believe that those cells may be used to re-establish or expand the threatened population by somatic cell nuclear transfer (SCNT), a unique utilisation of preserved genetic material (Loi et al., 2008; Saragusty et al., 2016; Hildebrandt TB et al., 2018).

SCNT has tremendous potential, not only for the rescue of endangered breeds and species (Loi et al., 2001), but also as a reproductive technology for genetically valuable farm animals or for generation of transgenic animals (Rodriguez-Osorio et al., 2009).

Theoretically, SCNT is a simple technique, involving removal of nuclear DNA from an oocyte and its replacement with a somatic cell nucleus. Yet, despite its simplicity, the efficiency is basically the same since the first cloned animal was delivered (Wilmut et al., 1997). For this reason, many attempts to modify/improve SCNT efficiency have been reported (luso et al., 2013; Czernik et al., 2016). These improvements concerned the technical aspects (Wakayama et al., 2010, Czernik et al., 2016) as well as attempts as bulk or targeted modification of donor nucleus, before or af- ter embryo reconstruction (Wakayama, 2007; Wakayama and Wakayama, 2010; luso et al., 2015). This review will address the main improvements in the SCNT technique, as well as the role of mitochondria in cloned embryos and foetuses.

\section{Technical improvements in SCNT}

\section{Improvement of the technique}

The traditional method of cloning (TDC) used in the majority of mammalian nuclear transfer laboratories involves the enucleation of matured (MII) oocytes, and subsequently replacing it (by different approaches) with a donor somatic nucleus (known as Nuclear Transfer) (Fig. 1A). The cytoplasm of human oocytes as well as laboratory animals like mouse and rat is clear and "transparent" under the microscope, which facilitates identification of MII chromosomes, hence their easy removal. On the other hand, the cytoplasm of large domestic animal's oocyte is much darker, due to high lipid content, making it necessary to use fluorescence staining Hoechst 33342, ultraviolet (UV) exposure and cytochalasin B treatment during enucleation. Exposure to UV, however, has harmful effects on embryonic development (Gil et al., 2012). To avoid UV-related damages, luso and colleagues developed a new enucleation method in a large animal model, the sheep (luso

Abbreviations used in this paper: IVF, in vitro fertilization; IVP, in vitro produced; Mfn2, mitofusin 2; MII, metaphase II; mtDNA, mitochondrial DNA; NR, nuclear reprogramming; SCNT, somatic cell nuclear transfer; TSA, trichostatin A; UV, ultraviolet.

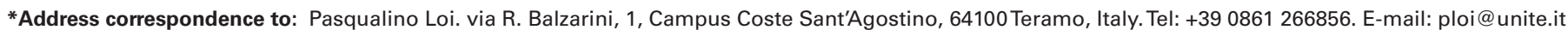
(iD) https://orcid.org/0000-0003-4631-7663

"Current address: Wellcome Trust/Cancer Research UK Gurdon Institute, University of Cambridge, Cambridge CB2 10N, UK.
}

Submitted: 27 September, 2018; Accepted: 11 October, 2018.

ISSN: Online 1696-3547, Print 0214-6282 
et al., 2013). Those authors showed significantly higher blastocyst rates when SCNT was performed without exposure of the oocytes to UV, as compared to the traditional method.

Traditional method of nuclear transfer needs expensive equipment, as well as highly skilled personnel. To avoid that, several laboratories adopted a more economic procedure called Hand Made Cloning (HMC) (Vajta, 2007). The first successful HMC was done by Peura and colleagues (Peura et al., 1998). The technique then spread to the field of large domestic animal: buffalo (George et al., 2001), sheep (Zhang et al., 2013), horse (Lagutina et al., 2005), and pig (Du et al., 2007). In a further modification, researchers have successfully enucleated zona-free oocytes using sharp microblade, and attached the enucleated oocytes and donor cells using phytohemagglutinin, without any sophisticated equipment (Fig. 1B).

Reconstruction of the enucleated oocytes can be performed by direct injection or by electrofusion of the somatic cell to the cytoplasm of the oocyte. There are two major methods for direct injection of donor cells' nuclei. In the traditional way, membrane of the donor cell is lysed by repeated aspiration and ejection with a micro-capillary. The alternative way of reconstruction uses the Piezo device. The Piezo-driven technique, also known as the "Honolulu technique", was first used by Wakayama, then at the University of Hawaii, to produce the first cloned mouse (Wakayama et al., 1998).

The source of the donor nucleus is a crucial aspect when aiming to increase nuclear reprogramming efficiency. Most of the information available is on mouse model (Wakayama, 2007). The most commonly used donor cells, for ease of retrieval, are the cumulus cells (Wakayama et al., 1998). In addition to cumulus cells, tail tip fibroblasts (Wakayama and Yanagimachi, 1999), Sertoli cell (Ogura et al., 2000), foetal fibroblasts (Wakayama and Yanagimachi, 2001a), embryonic stem cells (Wakayama et al., 1999), natural killer T cells (Inoue et al., 2005), and primordial germ cells (Miki et al., 2005) have all successfully been used. In large mammals, adult and foetal fibroblasts, cumulus cells, and embryo-derived cell lines were used (Kato and Tsunoda, 2010; Akagi et al., 2014). However, even though development to the blastocyst stage was sometimes reported to have been improved in nuclear transfer embryos, especially in those reconstructed with embryonic cells, the percentage of clones developing to term is still disappointedly low.

Without deeply touching the issue, which was thoroughly discussed in authoritative reviews, cloned embryos display a wide array of epigenetic alternation, including DNA methylation, histone acetylation, methylation, and non-coding RNA transcripts expression (Matoba and Zhang, 2018). Correcting these shortcomings will certainly improve mammalian cloning efficiency. In the next section, we critically describe the solutions thus far adopted to minimise epigenetic alterations typically found in cloned embryos/ conceptuses, and discuss the challenges ahead.

\section{Treatment with histone deacetylase inhibitors}

One of the biggest problems of cloned embryos is deacetylation of histones in the transferred cell nucleus. Acetylation of histones is generally associated with activation of gene transcription stemming from a more "open" chromatin structure. Zygotic gene activation, a crucial event at the beginning of zygotic genes transcription, occurs during early embryo development. Therefore, histone acetylation on transferred cell chromatin is important for proper zygotic gene transcription and embryo development that follows. However, it was reported that the level and state of several histone acetyla- tion marks in SCNT embryos chromatin were different from those in IVF embryos (Wang et al., 2007; Yamanaka et al., 2009). To improve cloning efficiency, several histone deacetylase inhibitors (HDACis) have been used (Fig. 1C). So far, one of the most effective and commonly used inhibitors is Trichostatin A (TSA) that inhibits class I and II HDACs. Treatment of cloned embryos with TSA represses deacethylation on histones in embryo chromatin (Wang et al., 2007), improves the transcriptional activities at the 2-cell stage, and increases the efficiency of full-term development in mice (Rybouchkin et al., 2006; Kishigami et al., 2006, 2007). TSA treatment of porcine cloned embryos also improved both preimplantation and full development (Li et al., 2008).

However, while the benefits arising from HDACis are incontestable in mouse, its effects on large animal remains controversial. In fact, TSA treated bovine SCNT embryos showed improved preimplantation development (Akagi et al., 2014), but no improvement in offspring rate (Sawai et al., 2012). Conversely, treatment of donor cells with TSA improved preimplantation development of embryos reconstructed with treated cells in buffalo (Luo et al., 2013). While in pigs, TSA treatment improves both pre-implantation development and offspring rate, in bovine and buffalo it improves only pre-implantation rate. Therefore, this method cannot be applied in large animal species.

\section{Impeding Xist expression}

One of the well-investigated epigenetic events in embryo development is $\mathrm{X}$ Chromosome Inactivation $(\mathrm{XCl})$, in female mammalian cells. Since in mammals' female cells have two $X$ chromosomes, one copy is silenced so as to have the same proportion of gene products as that of males (dosage compensation). Xist, a noncoding RNA that is transcribed from the silenced $X$ chromosome, is one of the better indicators when investigating the condition of $\mathrm{XCI}$. In fertilized pre-implantation embryos, Xist shows monoallelic expression from the maternal $X$ chromosomes; however, biallelic expression is observed in both inner cell mass and trophectoderm in cloned mice blastocysts (Nolen et al., 2005). Using Xist-deleted donor cells, to prevent this ectopic Xist expression, improved fullterm development more than 7-8 times as compared to the normal procedure in mice (Matoba et al., 2011; Fig. 1D). Surprisingly, correction of Xist expression improves not only transcripts from $X$ chromosome but also that from autosomes (Inoue et al., 2010). Moreover, injection of short interference RNA (RNAi) of Xist into reconstructed embryos, represses Xist expression transiently and improves full-term development of male (Matoba et al., 2011) but not female (Oikawa et al., 2013) cloned embryos. Ectopic expression of Xist is also observed in bovine (Inoue et al., 2010) and pig (Yuan et al., 2014, Zeng et al., 2016) cloned embryos and RNAi-mediated knockdown of Xist increases full-term development in male porcine cloned embryos (Zeng et al., 2016). Therefore, the partial conclusion is that Xist repression enhances cloned embryo development in males, and not only in the laboratory mouse.

\section{Histone lysine demethylase family member mRNA injection into embryos}

Methylation on histones is generally associated with repression of most of the genes transcription. Therefore, repressive marks on transferred donor cell chromatin, such as H3K9me3, are another epigenetic barrier in cloned embryos that prevents proper gene transcription after zygotic gene activation. Removal of histone 
A

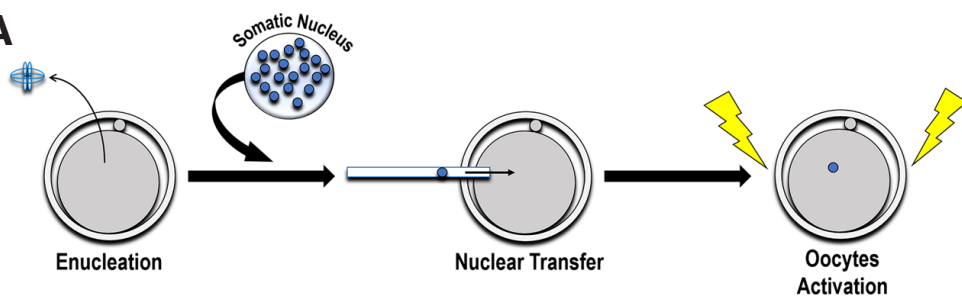

B

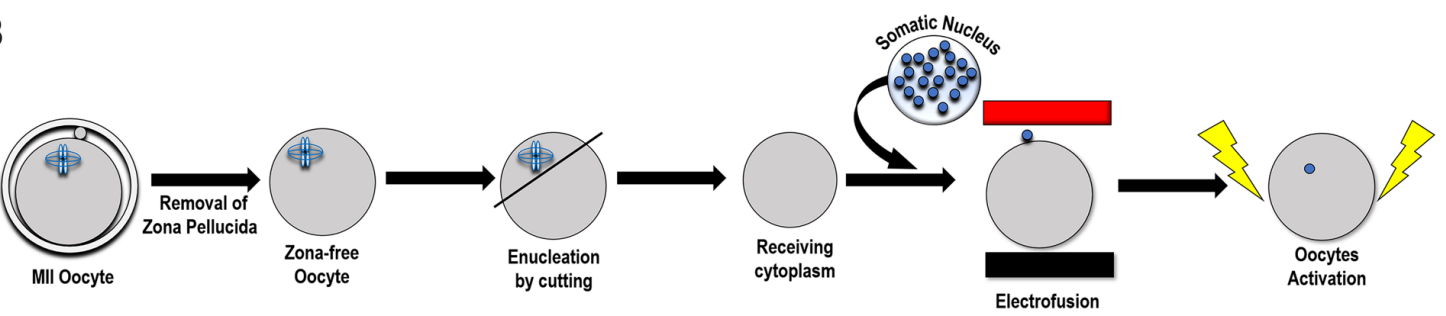

C

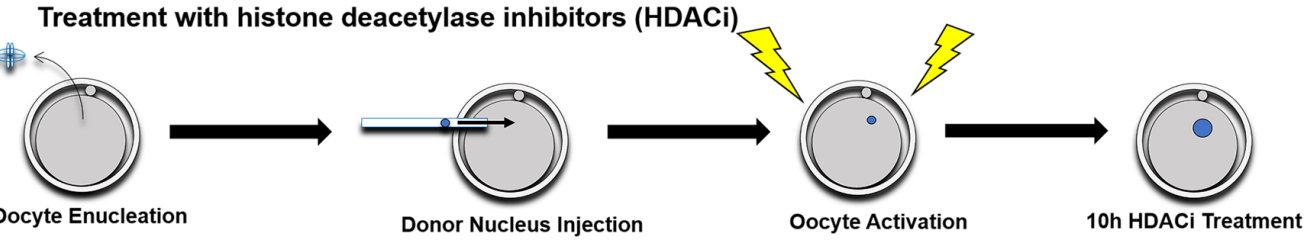

D

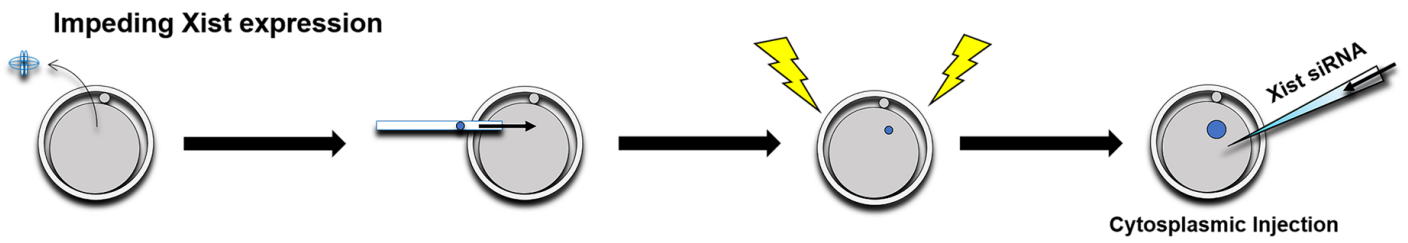

E

Injection of histone lysine demethylase (KDM) family mRNA into embryos

of Xist siRNA

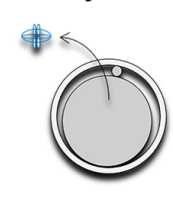
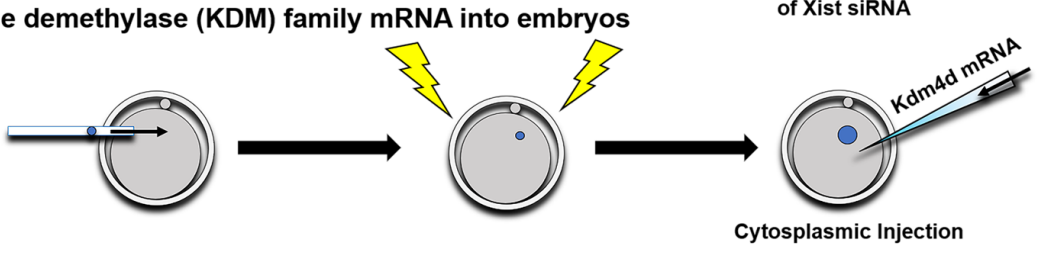

$\mathbf{F}$

Exogenous expression of Protamine 1 (Prm1) gene in Somatic Donor Nuclei

of Kdm4d mRNA
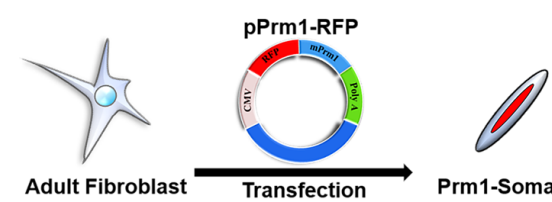

Adult Fibroblast Transfection $\longrightarrow$ Prm1-Somatic Nucleus
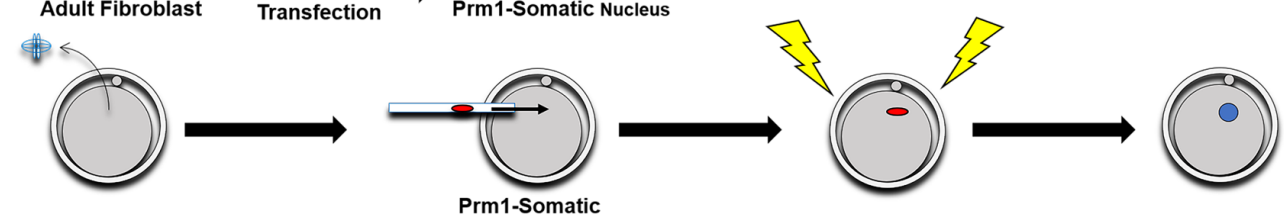

Nucleus Injection

Fig. 1. Improvements in somatic cell nuclear transfer (SCNT) techniques. (A) Traditional cloning (TDM). The MII plate is removed from the oocyte by micromanipulation, the enucleated oocyte is directly injected with the somatic donor nucleus and subsequently artificially activated. (B) Handmade cloning (HMC). The matured oocyte is exposed to Pronase to remove the zona pellucida; zona-free oocytes are enucleated by cutting with a micro sharpblade, the somatic donor nucleus is aggregate with phytohemagglutinin and subsequently electro-fused with the ooplasm. Finally, the reconstructed embryo is artificially activated. (C) SCNT improvement by exposure of histone deacetylase inhibitors (HDACi) after reconstructed oocyte activation. (D) SCNT improvement by downregulation of Xist expression with siRNA. (E) SCNT improvement by ablation of the repressive histone mark, H3K9me3, through Kdm4d mRNA injection. (F) SCNT improvement by NT with protaminized somatic nucleus, through exogenous expression of human Protamine 1 gene (pPrm1-RFP). 
methylation has been achieved by injection of histone lysine demethylase into reconstructed embryos (Matoba et al., 2014; Fig. $1 \mathrm{E})$. This treatment significantly improves full-term development of cloned mice (Matoba et al., 2014) and macaque monkeys (Liu et al., 2018) of both sexes. This application has even been used in human SCNT (Chung et al., 2015). It is expected that this method will be applied to other mammals in the near future.

\section{Treatment of reconstructed embryos with ascorbic acid}

It is reported that ascorbic acid treatment improves efficiency of reprogramming somatic cells to induced pluripotent cells in mouse and human (Esteban et al., 2010). This report prompted cloning scientists to test the possibility of improving nuclear reprogramming in SCNT embryos. Actually, vitamin C treatment of cloned embryos improves both preimplantation development and pregnancy rate in pigs (Huang et al., 2011). Moreover, combinations of the three components: deionized BSA, TSA and ascorbic acid treatment significantly improved cloning efficiency in mice (Miyamoto et al., 2017; Azuma et al., 2018). It is believed that the mechanism of this improvement is through repression of ROS and/or production and reduction of methylation on histone H3K9.

\section{Exogenous expression of the protamine 1 (Prm1) gene in somatic donor nuclei}

The male gamete is the perfect nuclear transfer device. Its DNA, tightly packed around protamines, confers the sperm nucleus a hydrodynamic shape to easily reach and fertilise the female gamete (Samans et al., 2014). Upon entering the oocyte, the sperm genome "springs out," revealing its intrinsic totipotency. This may suggest that any successful NR strategy must mimic the nuclear reorganisation of the spermatozoon. In fact, this is the only nuclear formation the oocyte has evolved to deal with. Twenty years of experiments following the birth of "Dolly", resulting in thousands of SCNT-derived embryos, showed invariably that the nuclear organisation of a somatic cells is rarely reset by the oocyte.

Nuclear remodelling during spermatid maturation occurs through a time-regulated translation of mRNAs for histone variants that have accumulated earlier, in spermatogonia (Govine et al., 2013). Incorporation of such testis-specific histone variants into the chromatin leads to destabilisation of nucleosomes (Rathke et al., 2014). Subsequently, post-translation modifications of the histone variants further prepare the ground for the incorporation of transition proteins first, and then protamines, that compact the nucleus (Shabazianet et al., 2007). At present, it is impossible to repeat the stepwise spermatid nuclear remodeling in a somatic cell. Surprisingly, it has been recently shown that expression of protamine 1 alone is sufficient to compact the nucleus in a shape reminiscent of those of spermatids (luso et al., 2015; Czernik et al., 2016; Palazzese et al., 2018) (Fig. 1F). Furthermore, these authors observed that the protamine, when binding to the DNA, replaces the somatic histones, including H3K9me3, a critical epigenetic barrier of SCNT reprogramming (luso et al., 2015). Additionally, protaminised nuclei injected into enucleated, sheep oocytes resulted in an increase in blastocyst formation rate compared to traditional nuclear transfer (14\% vs $4 \%$, respectively). Those unique results, that demonstrate a radical reorganisation of somatic chromatin from histone to protamine, provide a promising approach for improving mammalian cloning efficiency (luso et al., 2015).

\section{Embryo aggregation}

As we have described above, developmental outcomes of cloned embryos have improved by several kinds of treatments. However, the defects in the trophoblast cell linage, such as structural abnormalities and hyperplasia (Miki et al., 2009), have not been eliminated in any of these methods. Tetraploid embryo complementation is a widely-used application to prevent embryo lethality caused by placental dysfunction (Okada et al., 2007). Aggregation of inner cell mass (ICM) of diploid cloned embryos with trophectoderm (TE) derived from two or more tetraploid fertilised embryos can improve both full-term development ratio and placentamegaly in mice (Lin et al., 2011). Importantly, this improvement is not observed in case of whole embryo aggregation (Miki et al., 2009). Gestation period in large mammals is longer than in mice so this application might be more helpful for them.

\section{Mitochondria might affect the development of clones}

In this paragraph, we will address the limited success of the SCNT procedure from the mitochondrial perspective, an unexplored topic thus far. Investigations on mitochondria in SCNT procedures are limited to mtDNA hetero/homoplasmy in different tissues of cloned offspring (Lee et al., 2010). No data is available for an eventual role of mitochondrial dysfunction in developmental failure of the clones. Moreover, it is important to point that mitochondrial activity is strictly controlled by nuclear signals, suggesting that incomplete nuclear reprogramming in cloned nuclei might be responsible also for impaired mitochondrial function in cloned embryos/foetuses. Compared with nuclear reprogramming, which has been a leading research topic over the last ten years, very few, if any, studies have focused on problems related to the association between mitochondria and nuclear reprogramming.

In the next sub-sections, we will try to evaluate whether mitochondrial dysfunction affect the embryo proper, the placenta, and foetal development.

\section{Mitochondria in SCNT embryos}

Following fertilisation and up to implantation, the embryo depends on the function of existing mitochondria, present in the oocyte at ovulation (Spikings et al., 2006). As cell division begins, the total number of mitochondria within each blastomere decreases due to dilution with no new mitochondrial biosynthesis (John et al., 2010). Early stage embryos do not express the nuclear-encoded replication factors required to multiply mtDNA. Mitochondrial DNA and mtDNA-nuclear DNA (nDNA) interactions might be responsible for the different phenotypes resulting from nuclear cloning. Lack of nuclear-mitochondrial interaction at the molecular lever can explain the potentially high development rate of early embryos [(mouse: 52,8\% (Wakayama and Yanagimachi, 2001); sheep: 27,3\% (Wilmut et al., 1997); bovine: 69,4\% (Wells et al., 1999)], even in distant inter-species nuclear transfer (mouflon: 30,4\% (Loi et al., 2001). Replication defects of mitochondria may only be seen during embryogenesis, and play a role in post-implantation developmental defects. Consequently, any adverse influence on mitochondrial dysfunction (i.e., accumulation of mutational load to the mtDNA) may negatively impact the development of pre- and post-implantation cloned embryos.

Mitochondria exhibit an interesting quality maintenance function. They have numerous periods of fusion and fission. Active mitochondria are able to fuse with other mitochondria to transfer 
components and maintain or improve the function of damaged or poorly performing members (Mouli et al., 2009).

In mammals, three proteins are required for the fusion process. Two mitofusins are responsible for the fusion of the outer membrane, mitofusin 1 (MFN1) and mitofusin 2 (MFN2), while a single dynamic family member, OPA1, is required for inner membrane fusion. It is known that MFN2 plays a central role not only in the fusion process but is also responsible for key cellular functions such as oxidative metabolism, cell cycle maintenance, cell death, and mitochondrial axonal transport.

The importance of mitochondrial fusion in early embryo development was reported by Mishra and Chan (2014). It was later demonstrated that MFN2 plays a crucial role in mitochondrial fusion, which is essential for mouse blastocyst formation (Jiang et al., 2015). Inappropriate mitochondrial activity at the pronuclear stage is associated with early developmental arrest (Blerkom et al., 2000) and such embryos show decreased expression of mitochondrial genes (Duran et al., 2011).

Preliminary analysis of early mouse embryos stained with MitoTracker Green dye and evaluated by time-lapse microscopy showed minimal fusion process in SCNT blastocysts as compare to control groups (Czernik et al., unpublished data). Moreover, sheep and mouse early SCNT embryos show drastic differences in mitochondrial structure between SCNT and in vitro produced (IVP) blastocysts. Additionally, decreased density of mature mitochondria, very high degree of cytoplasmic vacuolisation, numerous cytoplasmic vesicles and autophagosomes, as well as significantly lower expression of major mitochondrial, autophagic and apoptotic proteins were all observed in SCNT embryos (Czernik et al., unpublished data).

\section{Mitochondria in SCNT placenta}

High frequency of first trimester losses, as well as late gestation and post-natal losses, are observed with SCNT pregnancies as compared to in vitro fertilised and in vivo control pregnancies (Heyman et al., 2002). In most SCNT pregnancies, high rate of foetal/embryonic loss is associated with placental malformation (Loi et al., 2006). Placental insufficiency resulting from abnormal cotyledon formation, decreased numbers of cotyledons, placental degeneration and reduced placental vascularisation are considered to be the cause for diseases typically documented in SCNT foetuses and neonates, including respiratory distress, malnutrition, and cardiopulmonary disease (Loi et al., 2006). The placenta has a crucial role in maternal control of foetal development and it represents an interface between the maternal environment and the foetus. Furthermore, many of the genes that regulate placental development also regulate foetal brain development (Murphy et al., 2006).

As was mentioned before, fusion of mitochondria plays crucial role in their proper function. It has been shown that mice, deficient in MFN2 protein, die in utero at mid-gestation of placental deficiency due to placental abnormalities, particularly disruption of the trophoblast giant cell layer (Chen et al., 2003). Additionally, it has been shown that low expression of MFN2 in human placentas is associated with mitochondrial damage in placental cells and unexplained miscarriage (Pang et al., 2013). Recently, Czernik et al., (2017) reported that deregulated expression of mitochondrial proteins (MFN2 and BCNL3L) cause abnormalities in early pregnancy placenta in sheep. Abnormalities were mainly presented as damaged and malformed mitochondria, as well as swollen endo- plasmic reticula (Czernik et al., 2017). Similar findings were also reported by Wakisaka and colleagues in mouse cloned placentas (Wakisaka et al., 2008). These observations clearly suggest that mitochondria in SCNT placentas do not work properly and this may negatively affect SCNT embryo development.

\section{Mitochondria in SCNT foetuses}

Many SCNT embryos are lost due to gestation and neonatal failures. Birth defects and high post-natal losses are seen in cloned cattle, sheep and pigs as well as in laboratory animals. Oversized livestock at birth (Bertolini et al., 2002), cloned calf syndrome (Wells et al., 2004) or more usually the large offspring syndrome (Young et al., 1998) are frequently observed in sheep and cow. Young and co-workers reported that oversized livestock at birth is related to imprinting dysregulation of IGF2R (Young et al., 2001) but full explanation of the underlying causes is still missing. Given the finding that mitochondria play a role in obesity (Ritov et al., 2005), it may well be that mitochondria abnormalities are involved in oversized live-stock neonates associated with cloned animals.

Major health problems include respiratory distress, circulatory problems, immune dysfunctions and kidney and heart failure. Moreover, problems with movement and balance have been observed in cloned animals, displaying uncoordinated limb movements, and therefore movement primarily by writhing on their abdomens (Wells et al., 2004).

In mouse mutants, homozygosity for both Mfn2or Mfn1 is lethal at early stages of development (Chen etal., 2007). Cerebellum-specific inactivation of Mfn1 or Mfn2 has been achieved by crossing Mfn1 loxP or Mfn2 ${ }^{\text {loxP }}$ mice. These mice express a cerebellum-specific Cre recombinase-driven promoter (pMeox2-cre). Mfn1 inactivation in the cerebellum resulted in mice with normal growth, development, and fertility. However, cerebellum-specific inactivation of the Mfn2 gene resulted in one-third of the mice dying within one day after birth and the surviving animals showing severe defects in movement and balance. The cerebellum of the Mfn2-deficient mice was only $25 \%$ the size of control mice at post-natal days $15-17$; this disparity was associated with reduced and deteriorating Purkinje cells and increased apoptosis of granule cells (Chen et al., 2007). The mouse Mfn2 pMeox2-cre mutants-associate abnormalities overlap with those observed in neonatal clones.

\section{Mitochondria and nuclear reprogramming}

The mitochondrial genome transcribes only 13 proteins, while the remainder mitochondrial proteins (1500-2000) are encoded by the nucleus, where the crucial mitochondrial genes have been transferred to benefit from more accurate (error-free) DNA replication. Critical nuclear and cytoplasmic interactions may be determined by the mitochondria. There is a great deal of communication between the nuclear and mitochondrial genomes, and this communication strictly controls mitochondrial function (Chappel, 2013). It is important to mention, once again, that the major reason for the low efficiency and abnormalities observed in SCNT embryos/foetuses is incomplete somatic cell Nuclear Reprogramming (NR). It might be that mitochondrial genome is not activated properly due to incorrect NR and this causes malfunction of the mitochondria, and hence abnormalities in cloned placentas and foetuses.

These findings suggest that mitochondria dysfunction might occur following nuclear transfer due to failure in nucleus-cytoplasmic interaction leading to failed nuclear remodelling. Proper nuclear 
remodelling is required to initiate mitochondria differentiation. Work report negative consequences of nuclear-cytoplasmic interaction for foetal development after bovine nuclear transfer, indicating complex oocytes cytoplasm-dependent epigenetic modifications and/ or nuclear DNA-mitochondrial disrupted interactions (Heindleder et al., 2005). It is also possible that mitochondrial dysfunction may contribute to activation of the apoptosis cascade, resulting in developmental defects and abnormalities (Schatten et al., 2005). To understand mitochondrial-nuclear interactions in reconstructed embryos more detailed studies will be needed.

\section{Conclusions}

Current efficiency of SCNThampers its practical application. The strategies put forth to improve its efficiency have had a negligible effect in farm animals, and minimal advancements have been achieved only in the mouse. Moreover, the unexpected mitochondrial dysfunctions in cloned embryos, reported for the first time by our group (Czernik et al., 2017), adds a further level of complication to cloning research. Clearly, it appears unlikely that all the biological constraints impairing cloning could be removed by a single treatment/protocol. Genome wide nuclear remodelling remains a priority in our opinion. Ideally, the perfect nuclear reprogramming strategy should work across all species, not only mammals. It is worthy to mention here that 24 species, including amphibian, fish, mammals, and insects have been successfully cloned so far. The message that this review would like to convey is that strategies described above have a potential to make a difference in nuclear reprogramming efficiency. The most promising strategies, in our opinion, are those acting on the entire genome, such as the forced expression of histone demethylases, or conversion of the chromatin structure typical for somatic cells to the spermatid-like structure (Fig. 1). Then, other issues, like mitochondrial dysfunction in normal clones or in interspecies SCNT, or lack of activation of the zygotic genome in the latter case, will need to be pinned down.

SCNT remains, after all, the most powerful way to reset the epigenetic memory in somatic cells. Any advancement in cloning research will have unquestionable benefits for regenerative medicine, species conservation, multiplication of desired genotypes or phenotypes, and lastly, for the introduction of the latest genomic research advancements like genome editing into farm animal breeding.

\section{Acknowledgments}

This project has received funding from the European Union's Horizon 2020 Research and Innovation Programme under the Marie SkłodowskaCurie grant agreement No. 734434, from National Science Centre, Poland by the grant No. 2016/21/D/NZ3/02610. The authors participate in the COST Action CA16119. The authors dedicate this paper to Andrzej K. Tarkowski, unforgettable titanic scientist in Developmental Biology.

\section{References}

AKAGI S, MATSUKAWAK, TAKAHASHIS (2014). Factors affecting the development of somatic cell nuclear transfer embryos in cattle. J Reprod Dev 60: 329-335.

AZUMA R, MIYAMOTO K, OIKAWA M, YAMADA M, ANZAI M (2018). Combination Treatment of A and Vitamin $C$ Improves the Efficiency of Cloning Mice by Somatic Cell Nuclear Transfer. J Vis Exp. 134: 57036.

BERTOLINI M, MASON J.B, BEAM SW, CARNEIRO G.F, SWEEN M L, KOMINEK DJ, MOYER AL, FAULATR, SAINZ RD, ANDERSON GP (2002). Morphology and morphometry of in vivo and in vitro-produced bovine concepti from early preg- nancy to term and association with high birth weights. Theriogenol 58: 973-994.

BLERKOM J. VAN, P. DAVIS, S. ALEXANDER (2000). Differential mitochondrial distribution in human pronuclear embryos leads to disproportionate inheritance between blastomeres: relationship to microtubular organization, ATP content and competence. Huma. Reprod. 15: 2621-2633.

CHAPPELS (2013). The role of mitochondria from mature oocyte to viable blastocyst. Obstet Gynecol Int. 183024.

CHEN H, DETMER SA, EWALD AJ, GRIFFIN EE, FRASER SE, CHAN DC (2003). Mitofusins Mfn1 and Mfn2 coordinately regulate mitochondrial fusion and are essential for embryonic development. J Cell Biol 20: 189-200.

CHEN H, MCCAFFERY JM, CHAN DC (2007). Mitochondrial fusion protects against neurodegeneration in the cerebellum. Cell 130: 548-562.

CHUNG YG, MATOBA S, LIU Y, EUM JH, LU F, JIANG W, LEE JE, SEPILIAN V, CHA KY, LEE DR, ZHANG Y (2015). Histone Demethylase Expression Enhances Human Somatic Cell Nuclear Transfer Efficiency and Promotes Derivation of Pluripotent Stem Cells. Cell Stem Cell 17: 758-766.

CZERNIK M, IUSO D, TOSCHI P, KHOCHBIN S, LOI P (2016). Remodeling somatic nuclei via exogenous expression of protamine 1 to create spermatid-like structures for somatic nuclear transfer. Nat Protoc 11: 2170-2188.

CZERNIK M, TOSCHI P, ZACCHINI F, IUSO D, PTAK GE (2017). Deregulated expression of mitochondrial proteins Mfn2 and Bcnl3L in placentae from sheep somatic cell nuclear transfer (SCNT) conceptuses. PLoS One 12: e0169579.

DU Y, KRAGH PM, ZHANG Y, LI J, SCHMIDT M, BOGH IB, ZHANG X, PURUP S, JORGENSEN AL, PEDERSEN AM, VILLEMOES K, YANG H, BOLUND L, VAJTA $G$ (2007). Piglets born from handmade cloning, an innovative cloning method without micromanipulation. Theriogenol. 68: 1104-1110.

DURAN HE, F. SIMSEK-DURAN, S.C. OEHNINGER, H.W. JONES, F. J. CASTORA (2011) The association of reproductive senescence with mitochondrial quantity, function, and DNA integrity in human oocytes at different stages of maturation. Fert. Stiril. 96: 384-388.

ESTEBAN MA, WANG T, QIN B, YANG J, QIN D, CAI J, LI W, WENG Z, CHEN J, NI S, CHEN K, LI Y, LIU X, XU J, ZHANG S, LI F, HE W, LABUDA K, SONG Y, PETERBAUER A, WOLBANK S, REDL H, ZHONG M, CAI D, ZENG L, PEI D (2010). Vitamin $C$ enhances the generation of mouse and human induced pluripotent stem cells. Cell Stem Cell 6: 71-79.

FAO. The Second Report on the State of the World's Animal Genetic Resources for Food and Agriculture, 2018. (B.D. Scherf, D. Pilling, eds.). FAO Commission on Genetic Resources for Food and Agriculture Assessments. Rome, Italy.

GEORGE A, SHARMA R, SHING KP, PANDA SK, SINGLA SK, PALTA P MANIK R, CHAUHAN MS (2001). Production of cloned and transgenic embryos using buffalo (Bubalus bubalis) embryonic stem cell-like isolated from in vitro fertilized and cloned blastocyst. Cell Reprogram 13: 263-272.

GIL MA, MASIDE C, CUELLO C, PARRILLA I, VAZQUEZ JM, ROCA J, MARTINEZ $E A(2012)$. Effect of Hoechst 33342 staining and ultraviolet irradiation on mitochondrial distribution and DNA copy number in porcine oocytes and preimplantation embryos. Mol Reprod Dev 79: 651-663.

GOVIN J. AND KHOCHBIN S (2013). Histone variants and sensing of chromatin functional states. Nucleus 4: 438-442.

HEYMAN Y, CHAVATTE-PALMER P, LEBOURHIS D, CAMOUS S, VIGNON X, RENARD JP (2002). Frequency and occurrence of late-gestation losses from cattle cloned embryos. Biol Reprod. 66: 6-13.

HIENDLEDER S, ZAKHARTCHENKO V, WOLF E (2005). Mitochondria and the success of somatic cell nuclear transfer cloning: from nuclear-mitochondrial interactions to mitochondrial complementation and mitochondrial DNA recombination. Reprod Fertil Dev 17: 69-83.

HILDEBRANDT TB, HERMES R, COLLEONI S, DIECKE S, HOLTZE S, RENFREE MB, STEJSKAL J, HAYASHI K, DRUKKER M, LOI P, GÖRITZ F, LAZZARI G, GALLI C (2018). Embryos and embryonic stem cells from the white rhinoceros. Nat Commun 9: 2589.

HUANG Y, TANG X, XIE W, ZHOU Y, LI D, ZHOU Y, ZHU J, YUAN T, LAI L, PANG $D$, OUYANG $\mathrm{H}$ (2011). Vitamin $\mathrm{C}$ enhances in vitro and in vivo development of porcine somatic cell nuclear transfer embryos. Biochem Biophys Res Commu. 411: 397-401.

INOUE K, KOHDAT, SUGIMOTO M, SADO T, OGONUKI N, MATOBAS, SHIURAH, IKEDA R, MOCHIDAK, FUJII T, SAWAI K, OTTE AP, TIAN XC, YANG X, ISHINO F, ABE K, OGURAA (2010). Impeding Xist expression from the active $X$ chromo- 
some improves mouse somatic cell nuclear transfer. Science 330: 496-499.

INOUE K, WAKAO H, OGONUKI N, MIKI H, SEINO K, NAMBU-WAKAO R, NODAS, MIYOSHI H, KOSEKI H, TANIGUCHI M, OGURAA (2005). Generation of cloned mice by direct nuclear transfer from natural killer T cells. Curr Biol 15: 1114-1118.

IUSO D, CZERNIK M, TOSCHI P, FIDANZA A, ZACCHINI F, FEIL R, CURTET S, BUCHOU T, SHIOTA H, KHOCHBIN S, PTAK GE, LOI P (2015). Exogenous Expression of Human Protamine 1 (hPrm1) Remodels Fibroblast Nuclei into Spermatid-like Structures. Cell Rep 13: 1765-1771.

IUSO D, CZERNIK M, ZACCHINI F, PTAK G, LOI P (2013). A simplified approach for oocyte enucleation in mammalian cloning. Cell Reprogram 15: 490-494.

JIANG GJ, PAN L, HUANG XY, HAN M, WEN JK, SUN FZ (2005). Expression of HSG is essential for mouse blastocyst formation. Biochem Biophys Res Commun 335: 351-355.

JOHN J. C. S., J. FACUCHO-OLIVEIRA, Y. JIANG, R. KELLY, R. SALAH (2010). Mitochondrial DNA transmission, replication and inheritance: a journey from the gamete through the embryo and into offspring and embryonic stem cells. Hum. Reprod. Update 16: 488-509.

KATO Y, TSUNODA Y (2010). Role of the donor nuclei in cloning efficiency: can the ooplasm reprogram any nucleus? Int J Dev Biol 54: 1623-1629.

KISHIGAMI S, BUI HT, WAKAYAMA S, TOKUNAGA K, VAN THUAN N, HIKICHI T, MIZUTANI E, OHTA H, SUETSUGU R, SATA T, WAKAYAMA T (2007). Successful mouse cloning of an outbred strain by trichostatin $A$ treatment after somatic nuclear transfer. J Reprod Dev 53: 165-170.

KISHIGAMI S, MIZUTANI E, OHTA H, HIKICHI T, THUAN NV, WAKAYAMA S, BUI HT, WAKAYAMA T (2006). Significant improvement of mouse cloning technique by treatment with trichostatin $\mathrm{A}$ after somatic nuclear transfer. Biochem Biophys Res Commun. 3;340: 183-189.

LAGUTINA I, LAZZARI G, DUCHI R, COLLEONI S, PONDERATO N, TURINI P, CROTTI G, GALLI C (2005). Somatic cell nuclear transfer in horses: effect of oocyte morphology, embryo reconstruction method and donor cell type. Reproduction 130: 559-567.

LEE JH, PETERS A, FISHER P, BOWLES EJ, ST JOHN JC, CAMPBELL KH (2010). Generation of mtDNA homoplasmic cloned lambs. Cell Reprog. 12: 347-355.

LI J, SVARCOVA O, VILLEMOES K, KRAGH PM, SCHMIDT M, BOGH IB, ZHANG Y, DU Y, LIN L, PURUP S, XUE Q, BOLUND L, YANG H, MADDOX-HYTTEL $P$, VAJTA $G$ (2008). High in vitro development after somatic cell nuclear transfer and trichostatin $A$ treatment of reconstructed porcine embryos. Theriogenol. 70 : 800-808.

LIN J, SHI L, ZHANG M, YANG H, QIN Y, ZHANG J, GONG D, ZHANG X, LI D, LI J (2011). Defects in trophoblast cell lineage account for the impaired in vivo development of cloned embryos generated by somatic nuclear transfer. Cell Stem Cell 8: 371-375.

LIU Z, CAI Y, WANG Y, NIE Y, ZHANG C, XU Y, ZHANG X, LU Y, WANG Z, POO M, SUN Q (2018). Cloning of Macaque Monkeys by Somatic Cell Nuclear Transfer. Cell 172: 881-887.

LOI P, CLINTON M, VACKOVA I, FULKA J JR, FEIL R, PALMIERI C, DELLA SALDA L, PTAK G (2006). Placental abnormalities associated with post-natal mortality in sheep somatic cell clones. Theriogenol. 1: 1110-1121.

LOI P, MATSUKAWA K, PTAK G, CLINTON M, FULKA J. JR, NATHAN Y, ARAV A (2008). Freeze-dried somatic cells direct embryonic development after nuclear transfer. PLoS One 3: e2978.

LOI P, PTAK G, FULKA J. JR, CAPPAI P, CLINTON M (2001). Genetic rescue of an endangered mammal by cross-species nuclear transfer using post-mortem somatic cells. Nat. Biotech 19: 962-964.

LUO C, LU F, WANG X, WANG Z, LI X, GONG F, JIANG J, LIU Q, SHI D (2013). Treatment of donor cells with trichostatin $A$ improves in vitro development and reprogramming of buffalo (Bubalus bubalis) nucleus transfer embryos. Theriogenol. 80: 878-886.

MATOBA S, INOUE K, KOHDA T, SUGIMOTO M, MIZUTANI E, OGONUKI N, NAKAMURA T, ABE K, NAKANO T, ISHINO F, OGURA A (2011). RNAi-mediated knockdown of Xist can rescue the impaired postimplantation development of cloned mouse embryos. Proc Natl Acad Sci USA 108: 20621-20626.

MATOBA S, LIU Y, LU F, IWABUCHI KA, SHEN L, INOUE A, ZHANG Y (2014). Embryonic development following somatic cell nuclear transfer impeded by persisting histone methylation. Cell 159: 884-895.

MATOBA S, ZHANG Y (2018). Somatic Cell Nuclear Transfer Reprogramming:
Mechanisms and Applications. Cell Stem Cell pii: S1934-5909(18)30300-X

MIKI H, INOUE K, KOHDA T, HONDA A, OGONUKI N, YUZURIHA M, MISE N, MATSUI Y, BABA T, ABE K, ISHINO F, OGURAA (2005). Birth of mice produced by germ cell nuclear transfer. Genesis 41: 81-86.

MIKI H, WAKISAKAN, INOUE K, OGONUKI N, MORI M, KIM J.M, OHTAA, OGURA, A (2009). Embryonic rather than extraembryonic tissues have more impact on the development of placental hyperplasia in cloned mice. Placenta 30: 543-546.

MISHRA P, CHAN DC (2014). Mitochondrial dynamics and inheritance during cell division, development and disease. Nat Rev Mol Cell Biol 15: 634-646.

MIYAMOTOK, TAJIMAY, YOSHIDAK, OIKAWAM, AZUMAR, ALLENGE, TSUJIKAWA T, TSUKAGUCHI T, BRADSHAW CR, JULLIEN J, YAMAGATA K, MATSUMOTO K, ANZAI M, IMAI H, GURDON JB, YAMADA M (2017). Reprogramming towards totipotency is greatly facilitated by synergistic effects of small molecules. Biol Open 6: 415-424.

MOULI PK, G. TWIG, AND O. S. SHIRIHAI (2009). Frequency and selectivity of mitochondrial fusion are key to its quality maintenance function. Biophysical $\mathrm{J}$. 96: 3509-3518.

MURPHY VE, SMITH R, GILES WB, CLIFTON VL (2006). Endocrine regulation of human fetal growth: the role of the mother, placenta, and fetus. Endocr Rev 27: 141-169.

NOLEN LD, GAO S, HAN Z, MANN MR, GIE CHUNG Y, OTTE AP, BARTOLOMEI MS, LATHAM KE (2005). X chromosome reactivation and regulation in cloned embryos. Dev Biol 279: 525-540.

OGURAA, INOUEK, OGONUKIN, NOGUCHIA, TAKANOK, NAGANOR, SUZUKIO, LEE J, ISHINO F, MATSUDAJ (2000). Production of male cloned mice from fresh, cultured, and cryopreserved immature Sertoli cells. Biol Reprod 62: 1579-1584.

OIKAWAM, MATOBAS, INOUEK, KAMIMURAS, HIROSEM, OGONUKIN, SHIURA H, SUGIMOTO M, ABE K, ISHINO F, OGURA A (2013). RNAi-mediated knockdown of Xist does not rescue the impaired development of female cloned mouse embryos. J Reprod Dev 59: 231-237.

OKADA Y, UESHIN Y, ISOTANI A, SAITO-FUJITA T, NAKASHIMA H, KIMURA K, MIZOGUCHI A, OHHORAM, MORI Y, OGATAM OSHIMARG, OKABE M, IKAWA $\mathrm{M}$ (2007). Complementation of placental defects and embryonic lethality by trophoblast-specific lentiviral gene transfer. Nat Biotech 25: 233-237.

PALAZZESE L, CZERNIK M, IUSO D, TOSCHI P, LOI P (2018). Nuclear quiescence and histone hyper-acetylation jointly improve protamine-mediated nuclear remodeling in sheep fibroblast. PLoS One13: e0193954.

PANGW, ZHANG Y, ZHAON, DARWICHESS, FUX, XIANGW (2013). Low expression of Mfn2 is associated with mitochondrial damage and apoptosis in the placental villi of early unexplained miscarriage. Placenta 34: 613-618.

PEURATT, LEWIS IM, TROUNSONAO (1998). The effect of recipient oocytes volume on nuclear transfer in cattle. Mol Reprod Dev 50: 185-189.

RATHKE C, BAARENDS WM, AWE S, RENKAWITZ-POHL R (2014). Chromatin dynamics during spermiogenesis. Biochim Biophys Acta 1839: 155-168.

RITOV MENSHIKOVA E.V, HE J, FERRELL R.E, GOODPASTER B.H, KELLEY D.E (2005). Deficiency of subsarcolemmal mitochondria in obesity and type 2 diabetes. Diabetes 54: 8-14.

RODRIGUEZ-OSORIO N, WANG Z, KASINATHAN P, PAGE GP, ROBL JM, MEMILI $E$ (2009). Transcriptional reprogramming of gene expression in bovine somatic cell chromatin transfer embryos. BMC Genomics 10: 190.

RYBOUCHKIN A, KATO Y, TSUNODA Y (2006). Role of histone acetylation in reprogramming of somatic nuclei following nuclear transfer. Biol Reprod74: 1083-1089.

SAMANS B, YANG Y, KREBS S, SARODE GV, BLUM H, REICHENBACH M, WOLF E, STEGERK, DANSRANJAVINT, SCHAGDARSURENGIN U (2014). Uniformity of nucleosome preservation pattern in Mammalian sperm and its connection to repetitive DNA elements. Dev Cell 14: 23-35.

SARAGUSTY J, DIECKE S, DRUKKER M, DURRANT B, FRIEDRICH BEN-NUN I, GALLI C, GÖRITZ F, HAYASHI K, HERMES R, HOLTZE S, JOHNSON S, LAZZARI G, LOI P, LORING JF, OKITA K, RENFREE MB, SEET S, VORACEK T, STEJSKAL J, RYDER OA, HILDEBRANDT TB (2016). Rewinding the process of mammalian extinction. Zoo Biol 35: 280-292.

SAWAIK, FUJIIT, HIRAYAMAH, HASHIZUME T, MINAMIHASHIA (2012). Epigenetic status and full-term development of bovine cloned embryos treated with trichostatin A. J Reprod Dev. 58: 302-309.

SHAHBAZIAN, M.D, GRUNSTEIN M (2007). Functions of site-specific histone acetylation and deacetylation. Annu Rev Biochem 76: 75-100. 
SCHATTEN H, PRATHER R.S, SUN Q.Y (2005). The significance of mitochondria for embryo development in cloned farm animals. Mitochondrion 5: 303-321.

SPIKINGS E. C., ALDERSON J, JOHN J. C. S (2006). Transmission of mitochondrial DNA following assisted reproduction and nuclear transfer. Hum. Reprod. Update 4: 401-415.

VAJTA G. (2007) Handmade cloning: the future way of nuclear transfer? Trends Biotechnol 25: 250-253.

WAKAYAMAT, RODRIGUEZI, PERRYAC, YANAGIMACHIR, MOMBAERTSP (1999). Mice cloned from embryonic stem cells. Proc NatlAcad Sci USA 96: 14984-14989.

WAKAYAMA T, YANAGIMACHI R (2001a). Mouse cloning with nucleus donor cells of different age and type. Mol Reprod Dev 58: 376-383.

WAKAYAMA T, YANAGIMACHI R (2001b). Effect of cytokinesis inhibitors, DMSO and the timing of oocyte activation on mouse cloning using cumulus cell nuclei. Reproduction. 122: 49-60.

WAKAYAMA S, WAKAYAMA T (2010). Improvement of mouse cloning using nuclear transfer-derived embryonic stem cells and/or histone deacetylase inhibitor. Int $J$ Dev Biol. 54: 1641-1648.

WAKAYAMAT, PERRY AC, ZUCCOTTI M, JOHNSON KR, YANAGIMACHI R (1998). Full-term development of mice from enucleated oocytes injected with cumulus cell nuclei. Nature 394: 369-374.

WAKAYAMA T, YANAGIMACHI R (1999). Cloning of male mice from adult tail-tip cells. Nat Genet 22: 127-128.

WAKAYAMAT (2007). Production of cloned mice and ES cells from adult somatic cells by nuclear transfer: how to improve cloning efficiency? J Reprod Dev. 53: 13-26.

WAKISAKA N, INOUE K, OGONUKI N, MIKI H, SEKITA Y, HANAKI K, AKATSUKA A, KANEKO-ISHINO T, ISHINO F, OGURA A (2008). Ultrastructure of placental hyperplasia in mice: comparison of placental phenotypes with three different etiologies. Placenta 29: 753-759.

WANG F, KOU Z, ZHANG Y, GAO S (2007). Dynamic reprogramming of histone acetylation and methylation in the first cell cycle of cloned mouse embryos. Biol Reprod 77: 1007-1016.

WELLS DN, FORSYTH JT, MCMILLAN V, OBACK B (2004). The health of somatic cell cloned cattle and their offspring. Cloning Stem Cells 6: 101-110.

WILMUT I, SCHNIEKE AE, MCWHIR J, KIND AJ, CAMPBELL KHS (1997). Viable offspring derived from fetal and adult mammalian cells. Nature 385: 810-813.

YAMANAKAK, SUGIMURAS, WAKAI T, KAWAHARAM, SATO E (2009). Acetylation level of histone $\mathrm{H} 3$ in early embryonic stages affects subsequent development of miniature pig somatic cell nuclear transfer embryos. J Reprod Dev 55: 638-644.

YANG Y, WU D, LIU D, SHI J, ZHOU R, HE X, QUAN J, CAI G, ZHENG E, WU Z, LI $Z$ (2017). Mutation of the XIST gene upregulates expression of $X$-linked genes but decreases the developmental rates of cloned male porcine embryos. $\mathrm{Mol}$ Reprod Dev 84: 525-534.

YOUNG L.E, SINCLAIR K.D, WILMUT I (1998). Large offspring syndrome in cattle and sheep. Rev. Reprod 3 : 155-163.

YOUNG LE, FERNANDES K, MCEVOY TG, BUTTERWITH SC, GUTIERREZ CG, CAROLAN C, BROADBENT PJ, ROBINSON JJ, WILMUT I, SINCLAIR KD (2001). Epigenetic change in IGF2R is associated with fetal overgrowth after sheep embryo culture. Nat Genet 27: 153-154.

ZENG F, HUANG Z, YUAN Y, SHI J, CAI G, LIU D, WU Z, LI Z (2016). Effects of RNAi-mediated knockdown of Xist on the developmental efficiency of cloned male porcine embryos. J Reprod Dev 62: 591-597.

ZHANG P, LIU P, DOU H, CHEN L, CHEN L, LIN L, TAN P, VAJTA G, GAO J, DU $Y, M A R Z$ (2013). Handmade cloned transgenic sheep rich in omega-3 fatty acids. PloS One. 8: e55941. 


\section{Further Related Reading, published previously in the Int. J. Dev. Biol.}

The effect of amniotic membrane stem cells as donor nucleus on gene expression in reconstructed bovine oocytes Hassan Nazari, Abolfazl Shirazi, Naser Shams-Esfandabadi, Azita Afzali and Ebrahim Ahmadi Int. J. Dev. Biol. (2016) 60: 95-102 https://doi.org/10.1387/ijdb.160010hn

Reprogramming of somatic cells and nuclei by Xenopus oocyte and egg extracts Alexander A. Tokmakov, Tetsushi Iwasaki, Ken-Ichi Sato and Shinji Kamada Int. J. Dev. Biol. (2016) 60: 289-296 https://doi.org/10.1387/ijdb.160163at

SCNT versus iPSCs: proteins and small molecules in reprogramming Fei Han, Xia Li, Dandan Song, Shaoshuai Jiang, Qun Xu and Yunhai Zhang Int. J. Dev. Biol. (2015) 59: 179-186 https://doi.org/10.1387/ijdb.150042fh

Amphibian interorder nuclear transfer embryos reveal conserved embryonic gene transcription, but deficient DNA replication or chromosome segregation

Patrick Narbonne and John B. Gurdon Int. J. Dev. Biol. (2012) 56: 975-986 https://doi.org/10.1387/ijdb.120150jg

The influence of donor nucleus source on the outcome of zebrafish somatic cell nuclear transfer Kannika Siripattarapravat, Boonya Pinmee, Eun-Ah Chang, Juan D. Muñoz, Koichi Kawakami and José B. Cibelli Int. J. Dev. Biol. (2010) 54: 1679-1683 https://doi.org/10.1387/ijdb.103189ks
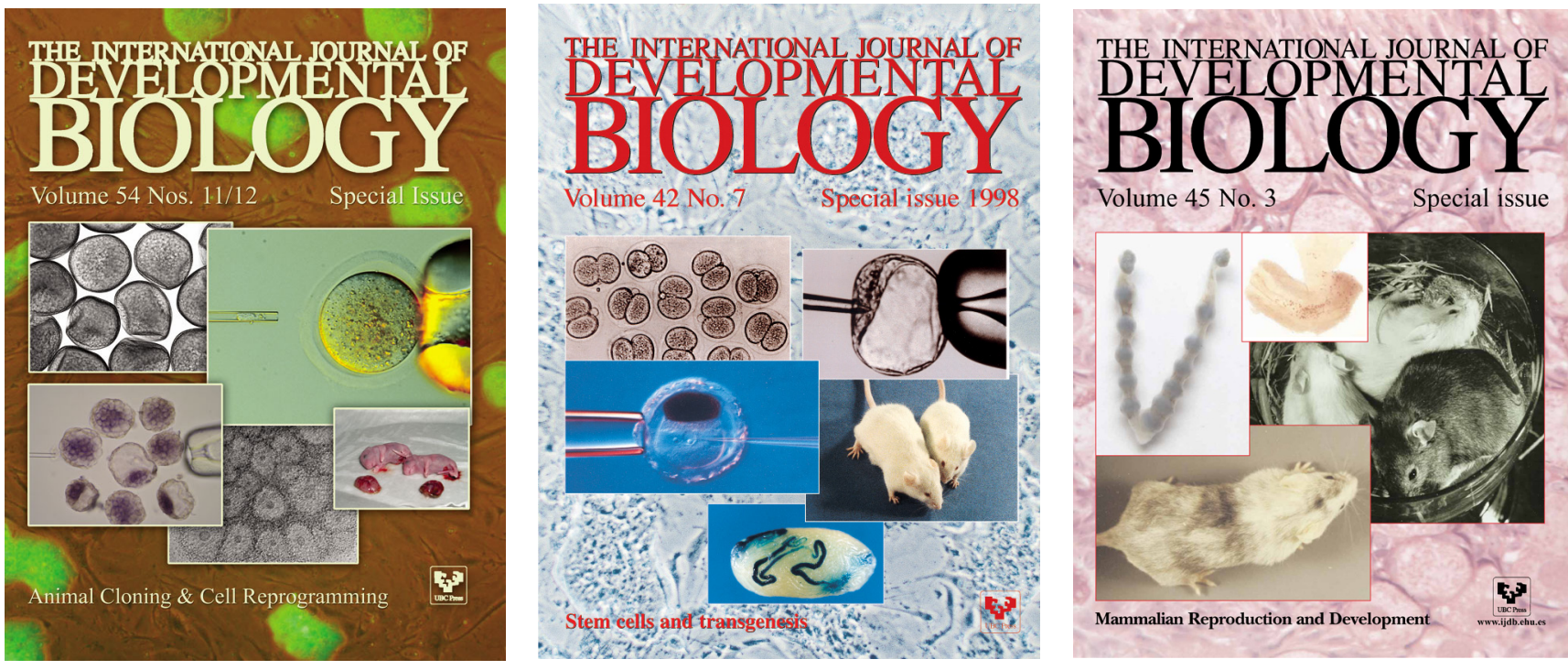